\title{
Eirini-Sophia Kiapidou
}

\section{Writing letters and chronography in parallel: the case of Michael Glykas' letter collection and Biblos Chronike in the 12th century}

Abstract: This paper focuses on the 12th-century Byzantine scholar Michael Glykas and the two main pillars of his multifarious literary production, Biblos Chronike and Letters, thoroughly exploring for the first time the nature of their interconnection. In addition to the primary goal, i.e. clarifying as far as possible the conditions in which these two works were written, taking into account their intertextuality, it extends the discussion to the mixture of features in texts of different literary genre, written in parallel, by the same author, based on the same material. By presenting the evidence drawn from the case of Michael Glykas, the paper attempts to stress the need to abandon the strictly applied taxonomical logic in approaching Byzantine Literature, as it ultimately prevents us from constitute the full mark of each author in the history of Byzantine culture.

Adresse: Dr. Eirini-Sophia Kiapidou, University of Patras, Department of Philology, Univesity Campus, 26504 Rio Achaia, GreECE; ekiapidou@upatras.gr

According to the traditional method of approaching Byzantine Literature, as applied - under the influence of classical philology - in the fundamental works of Karl Krumbacher, ${ }^{1}$ Herbert Hunger ${ }^{2}$ and Hans-Georg Beck ${ }^{3}$ and indeed repro-

I wish to thank Professor Stratis Papaioannou as well as the two anonymous readers for making valuable suggestions on earlier versions of this paper. All remaining mistakes, of course, are mine.

1 K. KRUMBACHER, Geschichte der byzantinischen Litteratur von Justinian bis zum Ende des oströmischen Reiches (527-1453). München 1891.

2 H. Hunger, Die hochsprachliche profane Literatur der Byzantiner. Handbuch der Altertumwissenschaft 12.5.1, I-II. München 1978.

3 H.-G. BECK, Kirche und theologische Literatur im Byzantinischen Reich. München 1959; IDEM, Geschichte der byzantinischen Volksliteratur. München 1971. 
duced in later reference books, ${ }^{4}$ Byzantine texts are to be classified into smaller groups based on four main criteria: their medium (prose or verse), their literary genre, their secular or theological content, and their language (the learned or vernacular version of Greek they are written in), in conjunction, of course, with the time of their composition, following in this case the ordinary division of Byzantine history into Early, Middle and Late. ${ }^{5}$ Undoubtedly, this taxonomic reasoning has facilitated the study of the massive Byzantine literary production, which is thus divided into smaller units, as far as possible homogeneous (in terms of language, genre, content or time of composition) and therefore more easily accessible to study. Its influence was so determinant, however, that it has been extended to the study even of the individual writings of each scholar, especially when his work is rich and multifarious. As an immediate and fundamental consequence of this practice, the internal links that not surprisingly connect the works of different literary genre and content of the same author and constitute the full mark of each author in the history of Byzantine culture all these remain disregarded in modern scholarship. And this is true even for well-studied scholars of the class of Patriarch Photios from the 9th century or Michael Psellos from the 11th century, whose work has not yet been evaluated as a whole. ${ }^{6}$

One of the most typical cases of such a strictly applied taxonomical logic is the well-known 12th-century Byzantine scholar Michael Glykas, owing to the fact that all four of the above-mentioned classification criteria have been applied to his work. As a result, in the history of vernacular literature Glykas is primarily known as the creator of the two long poems he composed in prison and addressed to the emperor Manuel I Komnenos (1143-1180), depicting the poor con-

4 See indicatively the standard handbooks on Byzantine historiography: A. KARPOZELOS, Bu $\alpha v$ -

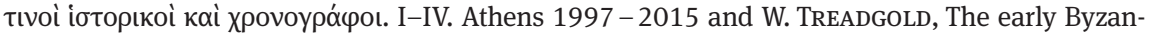
tine historians. New York 2007; IDEM, The middle Byzantine historians. New York 2013. For the strong impact of the "Krumbacher paradigm" on Byzantine Philology, the issues connected with its conceptual boundaries as well as the need for a new history of Byzantine literature, see the enlightening papers of P.A. AGAPITOS, Karl Krumbacher and the history of Byzantine literature. BZ 108 (2015), 1-52 and Contesting Conceptual Boundaries. Byzantine Literature and Its History. Interfaces 1 (2015), 62 -91; also P. OdoRico / P. AGAPITOS, Pour une "nouvelle" histoire de la littérature byzantine. Problèmes, méthodes, approches, propositions. Actes du Colloque international philologique, Nicosie-Chypre 25-28 mai 2000. Dossiers Byzantins, 1. Paris 2002.

5 For the methodological problems concerning the periodization of Byzantine history and literature, see AgAPITOS, Conceptual boundaries (as footnote 4 above) 73-78.

6 It is indicative that there are significantly fewer studies on Photios' Letters and Amphilochia than on the well-known Bibliotheca, while modern editions of Psellos' complete collection of letters and speeches have recently appeared (by S. PAPAIOANnou and I. PolEmis respectively). 
ditions of his detention and hoping for his release. ${ }^{7}$ His collection of proverbs is also mentioned alongside these poems. ${ }^{8}$ For the historian of learned Byzantine literature, on the other hand, Glykas is essentially the author of a world chronicle from Creation to the death of Alexios I Komnenos in 1118, under the title Biblos Chronike $^{9}$; although he is included among the few historiographers who left a rich collection of letters as well (= Letters), modern research has shown rather less interest in these, mainly on account of their theological content, unfamiliar and apparently less attractive to the readers of secular epistolography. ${ }^{10}$ In other words, different groups of scholars of Byzantine culture recognize Michael Glykas variously as a vernacular poet or as a chronographer or (more rarely) as an epistolographer, without taking into account the intertextual connections among these works.

The truth is, however, that the links between at least the Biblos Chronike and the Letters are strong, given that the theological issues developed in Glykas' correspondence are more or less to be found in his chronography as well. Sophronios Eustratiades, the editor of the Letters, does not deal with this issue: in the relevant introductory chapter, just two pages long, he confines himself to mentioning only a few words or phrases common to both texts. ${ }^{11}$ So the first step towards investigating the intertextual relationship between the two works was made rather recently by Apostolos Karpozelos, who at the end of his chapter

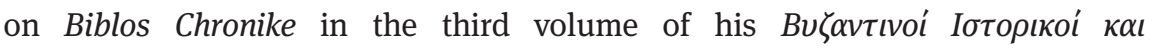

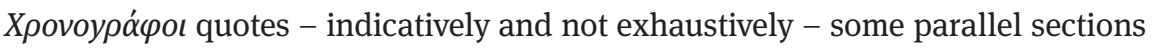
from the chronicle and the letters, expressing the opinion that material from the chronicle was most likely reused in the composition of the letters. ${ }^{12}$ Paul Magda-

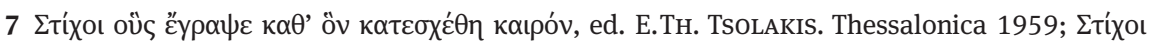

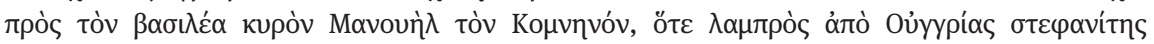

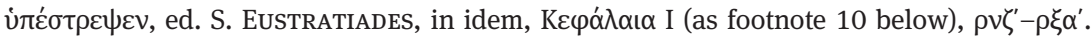

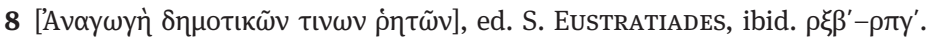

9 Michaelis Glycae Annales, ed. I. BeKKER. Bonn 1836. On the text see S. MAVRomati-Katsou-

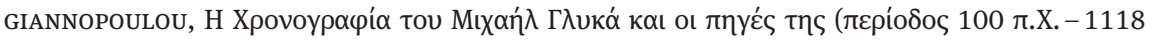

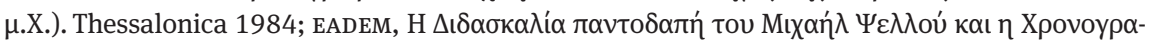

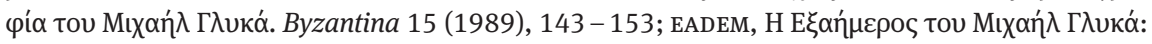

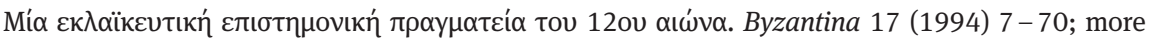
recently KARPOZELOS III (as footnote 4 above) 585-624.

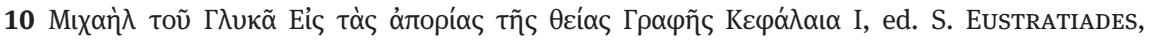
Athens 1906; II. Alexandria 1912. On the collection see: E.-S. KIAPIDOU, On the epistolography of Michael Glykas. Byzantina Symmeikta 21 (2011), 169-193; EADEM, Chapters, epistolary essays and epistles. The case of Michael Glykas' collection of ninety-five texts in the 12th century. Parekbolai 3 (2013), $45-62$.

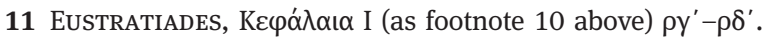

12 Karpozelos III (as footnote 4 above) 601-603. 
lino had earlier argued precisely the opposite point of view, namely that the chronography was written after the theological letters, without, however, adducing concrete evidence to support this assessment. ${ }^{13}$ In any case, the interest of both Karpozelos and Magdalino in the points of convergence between chronicle and letters starts from - and is basically limited to - the question of their dating (which text was written first), a question that still remains unanswered, mainly because neither scholar engages in an overall assessment of the conflicting evidence arising from the study of the parallel passages.

The present paper refocuses on the two main pillars of Michael Glykas' work, i.e. his chronicle and his letters, thoroughly exploring for the first time the nature of their interconnection on the basis of all their parallel passages. Its primary objective is, of course, to clarify as far as possible the conditions in which these two works were written, taking into account their intertextuality. The particular case of Glykas, however, as explained above, permits the extension of this research to an even more intriguing parameter: how in practice literary genres are mixed, not because the author consciously wishes to override their features or, conversely, fails to apply their rules, ${ }^{14}$ but simply because he adapts the same material to different texts according to the different demands and contexts of each.

Parallel passages between the Letters and the Biblos Chronike are found in $26^{15}$ of the 94 letters, scattered throughout both the letter collection and the chronicle. They can be classified into two main categories: those of theological (Table I) and those of chronographic (Table II) content.

The first category includes mainly ecclesiastical quotations and/or interpretative comments, corresponding to the theological questions discussed in Glykas' correspondence, which can also be found, verbatim or altered, in the Biblos Chronike as well. They constitute the majority of the parallel passages between the two works, and come mainly from the first part of the chronicle (Hexaemeron: 3.1-221.4), less from its second (Biblical History: 221.6-378.17) and third parts (Roman History: 379.2-457.11), and are totally absent from the fourth (Byzantine History: 460.2-625.4). This particular distribution is completely in line with the writing method of the chronicle: ${ }^{16}$ given that in the first two parts Glykas sought to comment on biblical events with references to Christian and secular

13 P. Magdalino, The Empire of Manuel I Komnenos, 1143 - 1180. Cambridge 1993, 382, note 233.

14 M. MulLEtT, The madness of genre. DOP 46 (1992), 233-243: 238.

15 Letters 4, 8, 11, 13, 16, 22, 26, 28, 29, 33, 34, 36, 37, 38, 39, 40, 41, 45, 50, 52, 61, 70, 72, 76, 80 and 91 .

16 Karpozelos III (as footnote 4 above) 599-600. 
literature, a method abandoned partly in the third and completely in the fourth part, it is reasonable that most parallels between the chronicle and the theological letters are found in the first two parts of the Biblos Chronike: ${ }^{17}$

\begin{tabular}{ll} 
based on Letters $^{18}$ & based on Biblos Chronike \\
\hline & Hexaemeron \\
$11.12-12.10 \sim 163.14-164.5$ & $7.8-10 \sim(38) 462.7-10$ \\
$13.13-17 \sim 182.2-7$ & $33.9-13 \sim(33) 371.6-10$ \\
$13.20-14.6 \sim 164.5-13$ & $48.19-49,2 \sim(39) 471.18-21$ \\
\hline $15.14-20 \sim 164.13-15$ & $50.4-50,10 \sim(39) 471.24-472.5$ \\
$15.21-16.14 \sim 164.16-165.10$ & $51.5-52,5 \sim(36) 398.17-399.5$ \\
$20.4-6$ and $20.9-21.24 \sim 165.11-$ & $52.16-53,8 \sim(36) 381.25-382.12$ \\
167.6 & \\
$26.5-27.2 \sim 167.6-17$ and $168.4-8$ & $56.10-13 \sim(39) 472.6-10$ \\
$27.6-11 \sim 155.11-17$ & $61.18-62,13 \sim(13) 164.13-165.8$ \\
$27.15-18 \sim 168.8-13$ & $67.10-12 \sim(37) 434.14-16$ \\
$28.1-13 \sim 168.13-169.12$ & $74.11-14 \sim(37) 433.15-19$ \\
$29.9-18 \sim 169.12-170.5$ & $81.13-82,6 \sim(34) 375.3-17$ \\
$30.6-12 \sim 170.5-12$ & $96.20-97,2 \sim(72) 244.15-19$ \\
$30.22-32.20 \sim 170.12-172.12$ & $99.5-8 \sim(72) 243.9-12 \sim 99.5-8$ \\
$36.2-37.12 \sim 173.11-175.3$ & $109.5-8 \sim(45) 24.2-7 \sim 109.5-8$ \\
$40.1-10 \sim 175.4-12$ & $123.18-124,12 \sim(72) 244.23-245.11$ \\
$40.20-41.1 \sim 175.12-18$ & $124.18-125,15 \sim(72) 242.9-243.3$ \\
$41.16-42.22 \sim 176.13-177.16$ & $127.11-17 \sim(11) 137.9-13 \sim 127.11-17$
\end{tabular}

17 In the following tables I and II, left column: $\underline{\text { underlined figures }}=$ excerpts preserved extensively in the Letters; double underlined figures = excerpts preserved extensively in Biblos Chronike; figures in italics = excerpts with loose textual similarities to one another. The serial number of each letter is indicated in brackets in both columns.

18 The following parallel passages of Table I between the Letters and the Biblos Chronike are

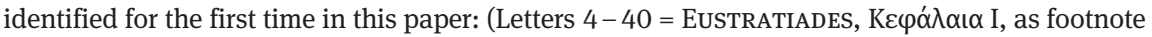
10 above) $11.12-12.10 \sim 163.14-164.5 ; 13.13-17 \sim 182.2-7$; $20.4-6$ and $20.9-21.24 \sim$ $165.11-167.6 ; 27.6-11 \sim 155.11-17 ; 57.21-58.1 \sim 182.19-183.1 ; 107.17-22 \sim$ $196.21-197.5 ; 137.9-13 \sim 127.11-17 ; 138.22-26 \sim 128.2-10 ; 203.5-204.3 \sim 314.4-$ 315.3; $262.8-14 \sim 434.3-8 ; 283.3-8 \sim 356.18-357.1 ; 283.17-21 \sim 296.3-7 ; 290.8-13$ 233.9-15; $299.26-300.14 \sim ~ 407.3-17$; 371.6- $10 \sim 33.9-13$; $375.3-17 \sim 81.13-82.6$; $381.25-382.12 \sim 52.16-53.8 ; 398.17-399.5 \sim 51.5-52.5 ; 433.15-19 \sim 74.11-14$; 434.14-16 67.10-12; 462.7-10 7.8-10; 464.15-465.12 339.1-340.13; 468.9-12

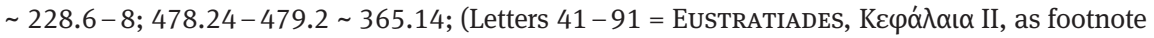
10 above) $2.21-3.5 \sim 373.19-374.6$; $3.20-4.2 \sim 204.16-19 ; 24.2-7 \sim 109.5-8$; $242.9-$ $243.3 \sim 124.18-125.15 ; 243.9-12 \sim 99.5-8 ; 244.15-19 \sim 96.20-97.2 ; 244.23-245.11 \sim$ $123.18-124.12 ; 263.14-23 \sim 315.3-10 ; 266.5-8 \sim 244.14-18$; $316.11-17 \sim 133.13-$ 134.4; 317.19-23 134.5-10; 318.2-12 134.16-135.6; 318.21-25 135.7-11; $318.26-319.3 \sim 136.6-10 ; 410.15-411.14 \sim 132.12-22 ; 414.26-415.23 \sim 158.17-$ 159.18; 416.8-10 141.13-15. 
$43.20-47.8 \sim 177.17-181.19$
$47.12-48.1 \sim 181.20-182.7$
$49.4-52.6 \sim 184.12-187.20$
$52.11-53.16 \sim 187.20-189.2$
$57.21-58.1 \sim 182.19-183.1$

(8) $96.16-98.12$ and $107.18-22 \sim 195.18-$ 197.18

$97.16-23 \sim 196.21-197.5$

$107.17-22 \sim 196.21-197.5$

(11) $137.9-13 \sim 127.11-17$

$\underline{\underline{138.22-26 \sim 128.2-10}}$

(13) $164.13-165.8 \sim 61.18-62.13$

(16) $203.5-204.3 \sim 314.4-315.3$

(22) $261.8-262.1 \sim 433.6-434.3$

$262.8-14 \sim 434.3-8$

$263.17-24 \sim 434.10-17$

$264.3-7 \sim 434.17-435.2$

$265.21-25 \sim 435.2-6$

(26) $283.3-8 \sim 356.18-357.1$

$283.17-21 \sim 296.3-7$

(28) $290.8-13 \sim 233.9-15$

(29) $299.26-300.14 \sim 407.3-17$

(33) $371.6-10 \sim 33.9-13$

(34) $375.3-17 \sim 81.13-82.6$

(36) $381.25-382.12 \sim 52.16-53$

$\underline{\underline{398.17-399.5 \sim 51.5-52.5}}$

(37) $433.15-19 \sim 74.11-14$

$434.14-16 \sim 67.10-12$

(38) $462.7-10 \sim 7.8-10$

$464.15-465.12 \sim 339.1-340.13$

(39) $468.9-12 \sim 228.6-8$

$471.18-21 \sim 48.19-49.2$

$471.24-472.5 \sim 50.4-50.10$

$472.6-10 \sim 56.10-13$

(40) $478.24-479.2 \sim 365.14$

(41) $2.21-3.5 \sim 373.19-374.6$

$3.20-4.2 \sim 204.16-19$

(45) $24.2-7 \sim 109.5-8$

(52) $73.16-22 \sim 345.22-346.8$

$74.15-22 \sim 346.13-20$

(72) $242.9-243.3 \sim 124.18-125.15$

$243.9-12 \sim 99.5-8$

$244.15-19 \sim 96.20-97.2$

$244.23-245.11 \sim 123.18-124.12$
$128.2-10 \sim$ (11) $138.22-26$

$132.12-22 \sim(91) 410.15-411.14$

$133.13-134.4 \sim(80) 316.11-17$

$134,5-10 \sim(80) 317.19-23$

$134.16-135.6 \sim(80) 318.2-12$

$135.7-11 \sim(80) 318.21-25$

$136.6-10 \sim(80) 318.26-319.3$

$141.13-15 \sim(91) 416.8-10$

$155.11-17 \sim$ (4) $27.6-11$

$158.17-159.18 \sim(91)$ (414.26-415.23

163.14-164.5 (4) $11.12-12.10$

163.5-13 (4) 13.20-14.6

$164.13-15 \sim$ (4) $15.14-20$

$164.16-165.10 \sim$ (4) $15.21-16.14$

165.11-167.6 (4) 20.4-6 and 20.921.24

167.6-17 and 168.4-8 (4) $26.5-27.2$

$168.8-13 \sim$ (4) $27.15-18$

$168.13-169.12 \sim$ (4) $28.1-13$

$169.12-170.5 \sim$ (4) $29.9-18$

$170.5-12 \sim$ (4) $30.6-12 \sim 170.5-12$

$170.12-172.12 \sim$ (4) $30.22-32.20$

$173.11-175.3 \sim$ (4) $36.2-37.12$

$175.4-12 \sim$ (4) $40.1-10$

$175.12-18 \sim$ (4) $40.20-41.1$

$176.13-177.16 \sim(4)$ 41.16-42.22

$177.17-181.19 \sim$ (4) $43.20-47.8$

$181.20-182.7 \sim(4) 47.12-48.1$

$182.2-7 \sim(4) 13.13-17$

$182.19-183.1 \sim(4) 57.21-58.1$

$184.12-187.20 \sim$ (4) $49.4-52.6$

$187.20-189.2 \sim$ (4) $52.11-53.16$

$195.18-197.18 \sim(8)$ 96.16-98.12 and

$107.18-22$

$196.21-197.5 \sim$ (8) $97.16-23$

$196.21-197.5 \sim$ (8) $107.17-22$

204.16-19 (41) $3.20-4.2$

Biblical History

228.6-8 (39) 468.9-12

$233.9-15 \sim(28) 290.8-13$

244.14-18 (76) 266.5-8

$296.3-7 \sim$ (26) $283.17-21$

$314.4-315.3 \sim$ (16) 203.5-204.3

$315.3-10 \sim$ (76) 263.14-23

$339.1-340.13 \sim$ (38) $464.15-465.12$

$345.22-346.8 \sim(52) 73.16-22$ 

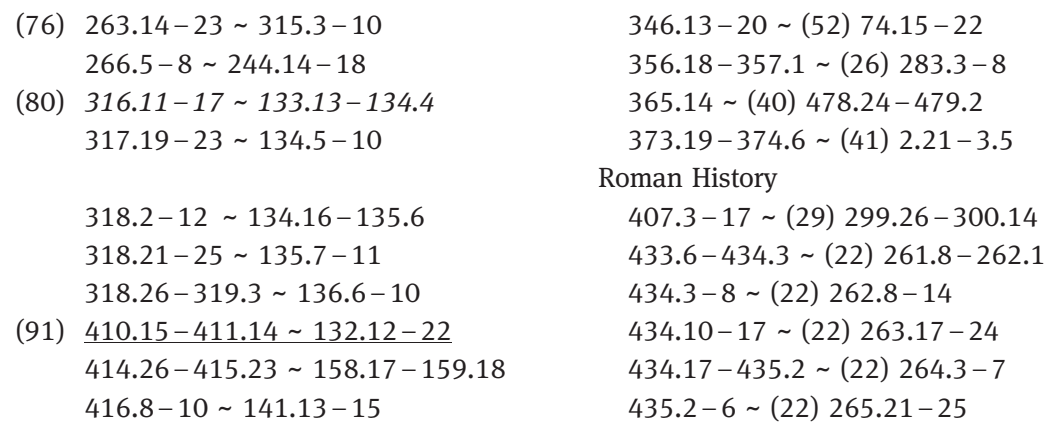

As short or extensive parallel passages occur in most cases verbatim (or almost verbatim) in the letters and the chronicle, it is only reasonable to assume that there is a connection between them, supporting thus the argumentation for their either early or late dating. Table I, however, presents a much more complex picture, since alongside the exactly parallel passages there are also several more that appear in either abbreviated or extended form or with loose phrasal similarities. ${ }^{19}$ At the same time, common topics may be traced in the letters and the chronicle, whose treatments are completely independent of each other, displaying no textual similarity. ${ }^{20}$ On top of all this, in one of the basic manuscripts of the Letters, the Parisinus gr. 228 from the second half of the 13 th century, ${ }^{21}$ which as a rule preserves shortened versions of the letters, Letter 4 in particular is preserved enriched with nine passages, which parallel the $B i$ blos Chronike verbatim. ${ }^{22}$ Given that the manuscript tradition of the epistolary corpus is much richer than the one Eustratiades knew or made use of in his

19 The most interesting of these are two parallel passages with Biblos Chronike. Each is traced twice in one letter: the first in Letter 4: 13.13-17 (verbatim parallel with Biblos Chronike: 182.2 -7) and again in Letter 4: 47.17-48.1 (part of an extensive parallel excerpt); the second in Letter 8: 107.18-22 (parallel with Biblos Chronike: 196.21-197.5) and again in Letter 8: 97.16-23 (verbatim parallel excerpt in an extensive parallel passage).

20 See indicatively the issue of Paul's inclusion among the twelve disciples of Christ (Letter 42

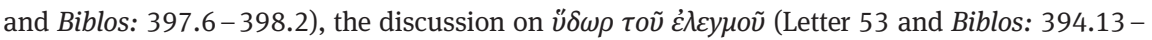
395.5), etc.

$21 \mathrm{H}$. Omont, Inventaire sommaire des manuscrits grecs de la Bibliothèque nationale I. Paris 1886, 26. See also K. Krumbacher, Michael Glykas. Eine Skizze seiner Biographie und seiner litterarischen Tätigkeit nebst einem unedierten Gedichte und Briefe desselben. Sitzungsber.

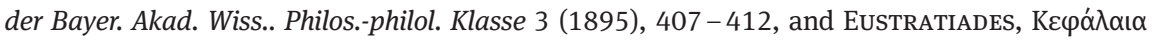
I (as footnote 10 above) $\rho \kappa \beta^{\prime}-\rho \kappa \sigma \tau^{\prime}$.

22 Biblos: 167.17-168.4, 169.4-12, 170.2-5, 172.12-173.11, 173.14-15, $175.18-$ 176.12, 177.20-178.3, 179.19-180.20, $182.7-184.12$ and 189.2-190.10. 
edition, ${ }^{23}$ one may assume that there are more connective elements between the two works, as a result of a subsequent phase of the collection's editing.

Because of the contradictory data regarding the nature of the interrelationship between the Biblos Chronike and the Letters, the two diametrically different assessments of Karpozelos and Magdalino as to which of the two texts preceded and which followed, are proved to be basically reliant on one part of the data alone, silently ignoring the rest. Moreover, they are limited to the parallel references of theological content, when those of chronological content, ignored by both scholars, are far more interesting, as is shown in Table II that follows: ${ }^{24}$

based on Letters ${ }^{25}$

$\underline{\underline{284.5-8 \sim 447.1-10}}$

(37) $\underline{\underline{430.11-19 \sim 112.3-20}}$

$434.17-19 \sim 445.7-8$

$447.21-448.2 \sim 455.9-12$

(40) $486.10-13 \sim 463.6-10$

$494.15-495.5 \sim 540.19-541.6$

(41) $3.13-17 \sim 510.10-14$

(50) $58.12-20 \sim 447.1-10$

(57) $122.23-123.27 \sim 572.14-575.19$

$124.1-125.9 \sim 476.17-477.13$

$125.10-126.19 \sim 508.12-510.15$

(61) $141.19-142.15 \sim 524.15-525.9$

$142.21-143.11 \sim 523.19-524.15$

$153.2-18 \sim 476.17-477.13$

(70) $\underline{\underline{232.25-233.1 \sim 447.1-10}}$

$\underline{\underline{233.3-6} \sim 508.12-510.15}$ based on Biblos Chronike

Hexaemeron

(37) $112.3-20 \sim 430.11-19$

Roman History

(37) $445.7-8 \sim 434.17-19$

(26) $447.1-10 \sim 284.5-8$

(50) $447.1-10 \sim 58.12-20$

(70) $447.1-10 \sim 232.25-233.1$

(37) $455.9-12 \sim 447.21-448.2$

(40) $463.6-10 \sim 486.10-13$

Byzantine history

(57) $476.17-477.13 \sim 124.1-125.9$

(61) $476.17-477.13 \sim 153.2-18$

(57) 508.12-510.15 125.10-126.19

(70) $508.12-510.15 \sim 233.3-6$

(41) $510.10-14 \sim 3.13-17$

(61) $523.19-524.15 \sim 142.21-143.11$

(61) $524.15-525.9 \sim 141.19-142.15$

(40) $540.19-541.6 \sim 494.15-495.5$

(57) $572.14-575.19 \sim 122.23-123.27$

This second group contains shorter (with the exception of Letters 57 and 61) and significantly fewer passages in comparison to the ones of the first group, appa-

23 Eustratiades himself declares that he did not take into account all the manuscripts he knew that preserve Michael Glykas' letters, because he had neither the time nor the means to study

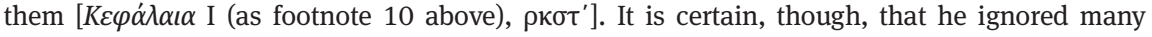
manuscripts - among them the precious codex Vatic. gr. 690 (1279-1280), that preserve almost the entire collection of Glykas and is one of the oldest extant manuscripts of the tradition (R. Devreesse, Bibliothecae Apostolicae Vaticanae Codices Vaticani graeci, III: Codices $604-$ 866. Città del Vaticano 1950, 154-160).

24 See note 17.

25 The parallel passages of Table II between the Letters and the Biblos Chronike are all identified for the first time in this paper. 
rently due to the almost exclusively theological subject matter of the letters. Qualitatively, however, these passages are most interesting for the study of the interrelationship between the Biblos Chronike and the Letters, since they relate the main historical parts of the chronicle, namely parts three and four.

They revolve around the following four topics of chronographical interest:

(a) the unusual manner of death of a ruler: Cleopatra's suicide by snakebite (Letter 37: 430.11-19 Biblos Chronike: 112.3-20), Domitian's murder of Titus with a fish (Letter 37: 434.17-19 Biblos Chronike: 445.7-8), the suicide of the emperor Quintillus (220 - 270) who slashed a vein (Letter 37: 447.21-448.2 Biblos Chronike: 455.9-12);

(b) lifting of excommunication: imposed on a monk (Letter 61: 142.21-143.11 Biblos Chronike: 523.19-524.15) and on a clergyman (Letter 61: 141.19-142.15 Biblos Chronike: 524.15-525.9);

(c) astrological predictions - demonic prophecies: incorrect calculations of the astrologer Valens (Letter 40: 486.10 - $13 \sim$ Biblos Chronike: 463.6-10), correct astrological calculations of Leo the Mathematician (Letter 40: 494.15-495.5 Biblos: 540.19-541.6), demonic prophecy of Maurice's execution (Letter 41: 3.13-17 Biblos Chronike: 510.10 -14);

(d) sincere repentance after committing a crime and God's forgiveness, of the emperors: Trajan for his sins (Letter 26: 284.5-8, Letter 50: 58.12-20, Letter 70: 232.25-233.1 Biblos Chronike: 447.1-10), Theodosios I for the massacre in Thessalonica (Letter 57: 124.1-125.9, Letter 61: 153.2-18 Biblos Chronike: 476.17477.13), Maurice for the killing of the Byzantine soldiers captured by the Avars due to his negligence (Letter 57: 125.10 -126.19, Letter 70: 233.3-6 Biblos Chronike: 508.12-510.15), John Tsimisces for the assassination of Nicephoros II Phocas (Letter 57: 122.23-123.27 Biblos Chronike: 572.14-575.19).

The most important topic for our discussion is the last (d), as it generally includes more extensive passages, repeated verbatim or abbreviated in two or possibly three letters of the collection. In particular:

(d1) Emperor Trajan (98-117) forgiven for his sins

In Letter 50 there is an almost verbatim parallel passage with the Biblos Chronike, while Letters 26 and 70 contain the exact same passage, pointing to the chronicle as the essential source of the detailed description.

(d2) Sincere repentance and forgiveness of Theodosios I (379-395) for the massacre in Thessalonica in 390

The same information about the massacre in Thessalonica in 390 by order of Theodosios I is found rearranged in Letter 61 and in Letter 57, which preserves 
the most detailed version. Letter 57 is the sole consolatory letter in the collection, and according to its title was addressed to Theodora, the beloved niece of Manuel I, who was in a desperate psychological state because of a crime she had committed out of jealousy. ${ }^{26}$ The parallel reference in the Biblos Chronike is more concise, mainly because the emphasis in the letter is on the description of Theodosios' psychology: on his initial (reasonable?) anger at the reaction of

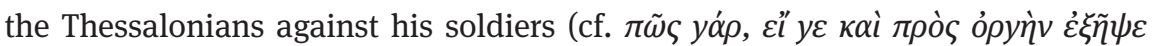

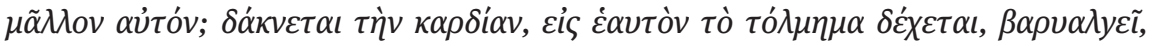
$\pi \lambda \eta \rho о \tilde{\tau} \alpha \iota$ $\theta$ vог̃ 124.14-15) and his honest later humility and humiliation, for the removal of the excommunication imposed on him by Bishop Ambrose of Me-

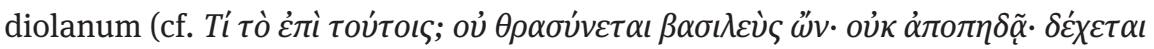

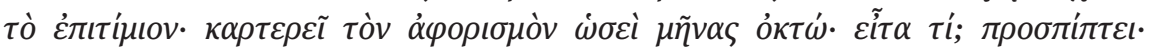

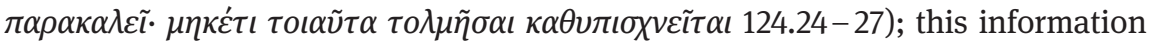
does exist in the chronicle as well, but is not developed as extensively as in the letter.

One detail in Letter 57, however, is of great significance: in dealing with the causes of the popular anger that led to the uprising of the citizens in Thessalon-

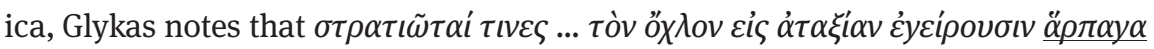

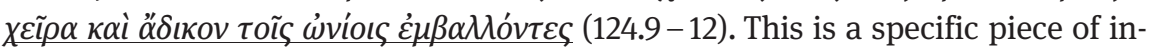
formation that is completely absent from the chronicle (cf. the indefinite refer-

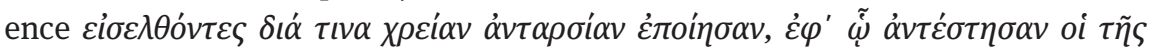

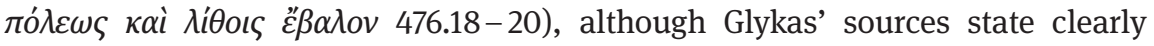

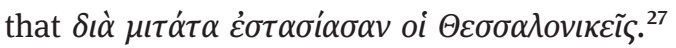

(d3) Sincere repentance and forgiveness of the emperor Maurice (582-602) for the killing of the Byzantine soldiers captured by the Avars due to his negligence ${ }^{28}$

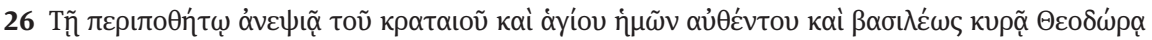

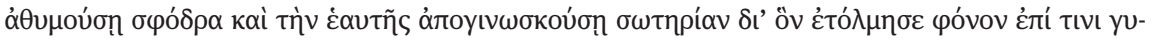

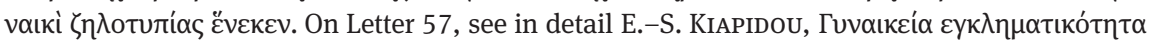

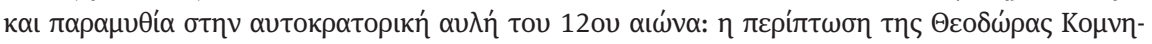

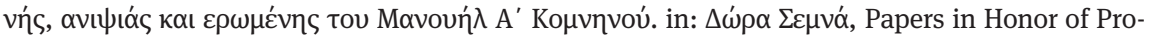
fessor Martha Karpozelou, eds. I. Polemis/A. Brouzos/A. Bogiatzoglou/D. Georgakopoulos

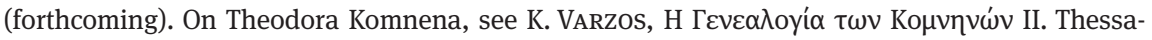
lonica 1984, $417-434$.

27 See the chronicles of Georgios Monachos (Georgii monachi chronicon, ed. C. DE BooR. Leipzig 1904, 577.4-5) and Georgios Kedrenos (Georgii Cedreni Historiarum compendium, ed. L. TARTAGLiA. Rome 2016, c. 339.2-6).

28 On the presence of this particular story in Byzantine historical sources, see KARPOZELOS I (as footnote 4 above) $504-506$. 
The most extensive description again occurs in Letter 57 (Letter 70 contains a simple reference to the event): despite the textual similarities with the chronicle, the narrative is more vivid in the letter, thanks to the use of short sentences and

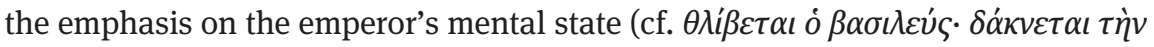

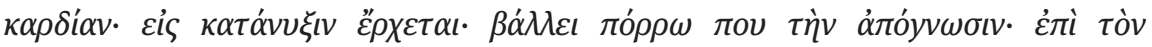

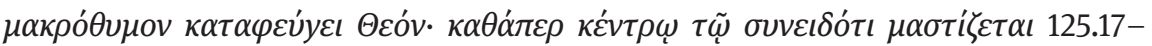
20). The letter also notes Maurice's correspondence with the monks (in particular

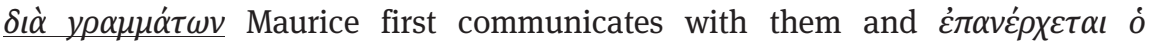

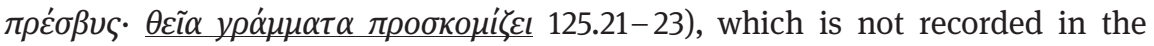
chronicle, although mentioned in its sources. ${ }^{29}$

(d4) Forgiveness of the emperor John Tsimisces (969-976) for the assassination of Nicephoros II Phocas (963-969)

Michael Glykas speaks of the murder of Nicephoros II Phocas and John Tsimisces' repentance for this deed in Letter 57 and, naturally, in the Biblos Chronike. Despite the several verbal similarities between these two parallel descriptions, the chronicle delivers more historical details, while the letter focuses particularly on Tsimisces' emotional state. However, here again there is a very interesting divergence that is worth stressing: while in his Biblos Chronike Glykas maintains a more or less balanced attitude towards the victim and the murderer, "inherited" from his main source at this point, John Skylitzes' Synopsis Historion, ${ }^{30}$ in the letter he clearly presents the facts from the perspective of the perpetrator: (a) Phocas removes Tsimisces from his military office $\pi \alpha \rho \dot{\alpha}$

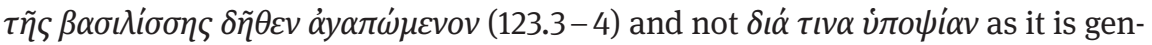
erally said in Biblos Chronike (572.19-20). (b) This - unfair, apparently, as indicated by $\delta \tilde{\eta} \theta \varepsilon v$ - decision leads to the (justified?) anger of Tsimisces ('A $\lambda$ ' ov'

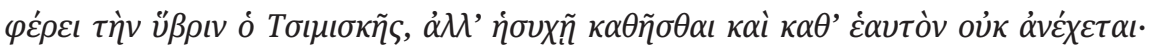

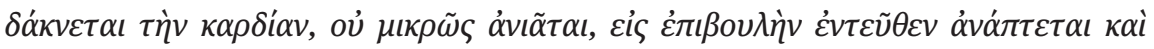

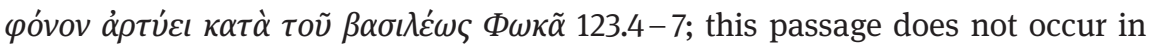

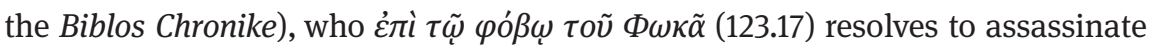

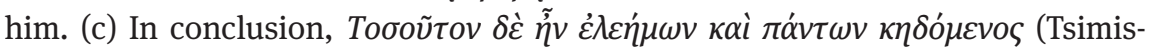

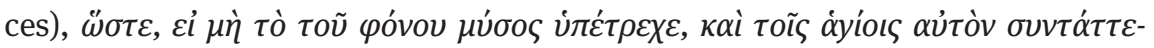

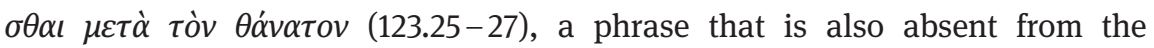
chronicle.

29 See Theophanes (Theophanis Chronographia I, ed. C. DE Boor. Bonn 1883, 284.25-26), Georgios Monachos (as footnote 27 above), 659.13-15 and Georgios Kedrenos (as footnote 25 above), c. 433.1.8-10.

30 Ioannis Scylitzae Synopsis historiarum, ed. J. ThURn. CFHB, 5. Berlin/New York 1973, 279.87-280.26. 
What is even more interesting is that the differences and additions to Letter 57 are not of Glykas' own inspiration (though they could have been), but are all found in Constantine Manasses' Synopsis Chronike, a historical text known to Glykas during the composition of his chronicle, though not used in the descrip-

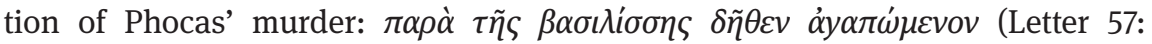

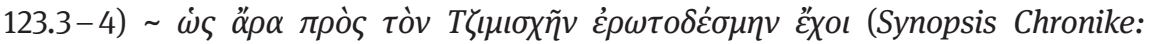

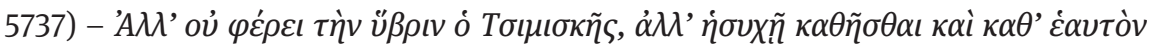

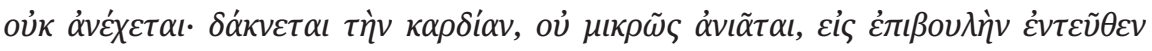

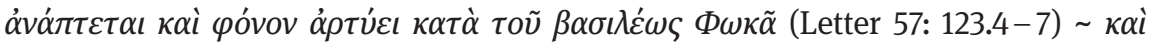

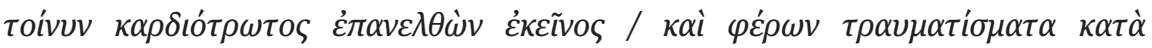

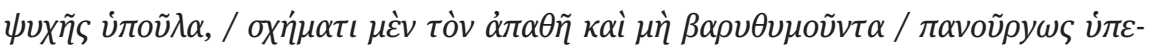

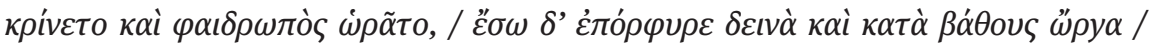

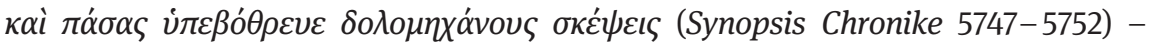

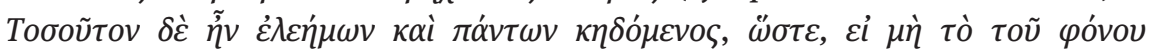

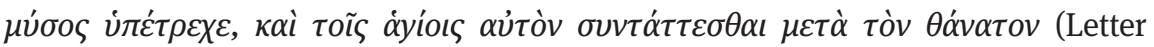

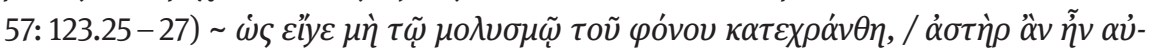

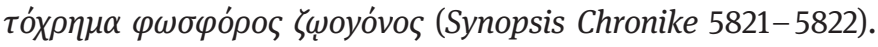

Glykas plainly makes significantly different use of his historical material in Letter 57 compared to the chronicle, which is to some degree natural, considering the different aims of the two works: the recording of historical truth in the one case, the consolation of the emperor's niece Theodora for having committed a murder out of jealousy in the other. In this context the little details added to the letter regarding the wretched psychological condition of the three emperors arising from their own criminal deeds as well as their honest repentance and humiliation, despite their high position, are justified, for they are directly related to the recipient of the letter, Theodora, and to Glykas' effort to strengthen her morale by writing her this consolatory letter. ${ }^{31}$ The problem is, however, that the differences between the two texts' accounts are not limited to verbal variations, but extend to specific items of historical information that are included in the other historical sources and the letter, but are curiously absent from their "natural environment”, i.e. Glykas' historical work.

Equally useful to our discussion is Letter 61, the second in which a number of parallel passages of chronographical interest are found. Letter 61 focuses on the issue of ecclesiastical excommunication, whether it is possible to lift it or not

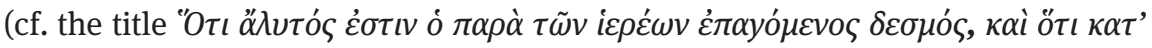

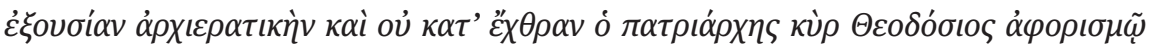

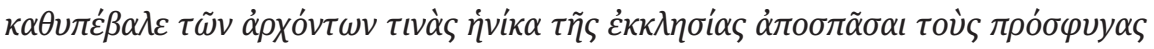

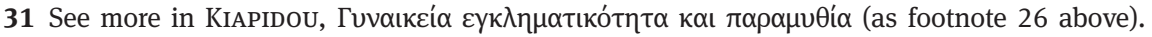




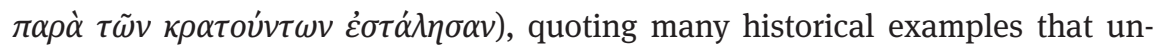
fortunately cannot be directly linked to the recipient, since his/her name is absent from the manuscript tradition. In three passages strong textual similarities are detected between the letter and the Biblos Chronike (141.19-142.15 524.15525.9, 142.21-143.11 523.19-524.15 and 153.2-18 476.17-477.13). In two more cases, however, there are parallel accounts with a common core of information but no further direct verbal similarities: (a) Pope Innocent's excommunication of the empress Eudoxia (147.18-151.3) and the emperor Arcadius (154.1-22) for the removal of John Chrysostom from the patriarchal throne (Biblos Chronike: 479.16-482.20), and (b) the punishment imposed on Bardas by Patriarch Ignatius (152.1-15 - Biblos Chronike: 544.4-545.5). Finally, the conflict between the emperor Valens and Bishop Ambrose of Mediolanum, mentioned in Letter 61 (153.19-26), is absent from the Biblos Chronike.

The data resulting from the analysis of Letters 57 and 61 refute once and for all, in my opinion, the view ascribing a direct textual dependence of the Letters on the Biblos Chronike. If Glykas had indeed written the chronicle first, if he had, that is, already finalized the content and language of his historical work, it would make most sense that he would have utilized this already shaped narrative in his letters as well; modified, of course, but nonetheless with visible similarities in language and content. This is not true of the form in which the two works have come down to us today. Nor, on the other hand, does the study of the parallel passages confirm the very reasonable conjecture that at least the chronicle's parallel theological passages are taken from the letters, where they would be expected to be developed more carefully and in greater detail, in accordance with the author's intention. As we have seen, more extensive accounts of that content are sometimes detected in the chronicle and not in the letters.

In my view, the conflicting evidence leads us inevitably to a kind of deadlock, because the discussion has in the first place been placed on a faulty basis: the collection of Michael Glykas' letters has in practice been considered as a single work, written at a particular period of time, and what has thereafter been investigated is whether that time should be placed before or after the completion of his chronicle. In reality, however, the corpus of letters, like any other collection, is a modular production and its individual parts (= chapters) were written at different times - at least in their original form (= letters). Therefore, what is true of the dating of one letter in relation to the chronicle does not necessarily apply to another and this perfectly illustrates the contradictory picture that we have come up against. In other words, it is from the outset problematic to seek a direct and unilinear (to or from one text or the other) relationship between two works that were written and edited - if variations in the manuscript tradition are to be taken into account as well - in completely different condi- 
tions. In addition to that, if it is true that for his commentary on the biblical quotations in the Hexaemeron Glykas relied on one or more anthologies of patristic passages, given the large number of sources which he should otherwise have had at his disposal, ${ }^{32}$ it should also be true that he uses the same notes, at will and simultaneously, in the answers he is unexpectedly asked to give through his letters on various theological issues, following in each case the wishes and interests of his correspondent. Only if we consider, consequently, that letters and chronicle were written in parallel, drawing material from the same body of Glykas' personal notes, can we justify the contradictory picture described in the above pages.

The traces of this simultaneous action are not limited only to the parallel sections of Glykas' works, but can also be identified at two other points: (a) In

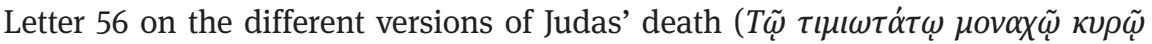

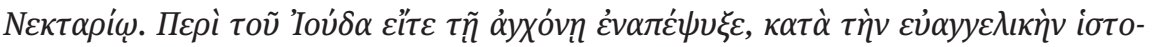

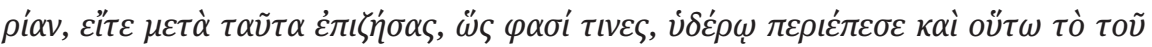

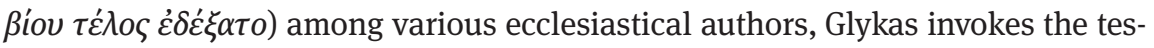
timony of Kedrenos, referring apparently to the following passage:

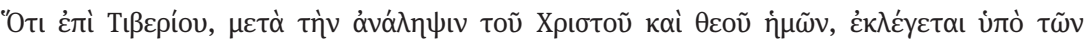

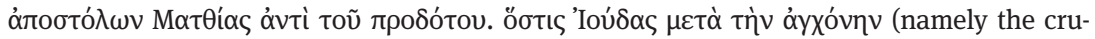

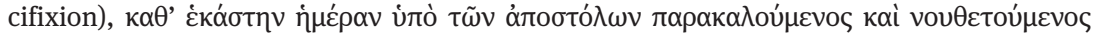

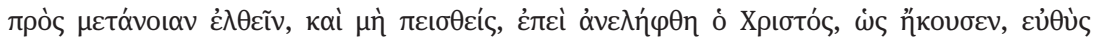

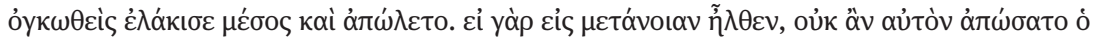

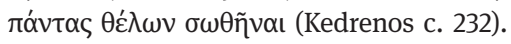

That Glykas includes a historical text, a chronicle, in his evidential sources can only be associated with the fact that he is familiar with this text and has used it for the composition of his own Biblos. It is, however, highly interesting that the question of Judas' death does not concern him at all in his chronicle, while in the rest of his correspondence he expresses no doubt that Judas was hanged. Apparently Glykas was responding here to a question from his correspondent Nektarios that had probably not yet been put to him when he was writing the chronicle. On the other hand, of course, there was no reason for him to mention this aspect in his chronicle, where the commonly accepted version is presented. (b) One may wonder how random is the fact that Michael Glykas prefaces his chronicle with a short proem in epistolary form, addressed to a young man:

32 KarPOZElos III (as footnote 4 above) 588. 


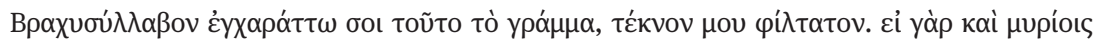

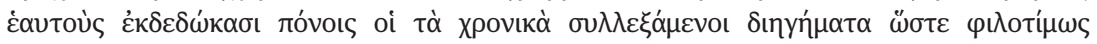

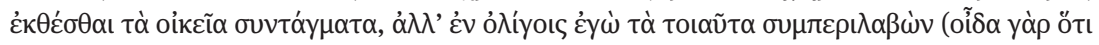

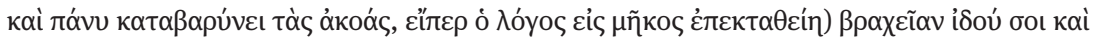

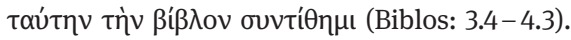

To sum up, in the case of Michael Glykas we see an author deriving from a body of personal notes material for two works of different genre, letters and historiography, inserting features of the one into the other, not necessarily consciously or intentionally (i.e. in order to form a hybrid text of his own), but rather inevitably, precisely because Glykas, whether he is writing a letter or his chronicle, is at the same time both an epistolographer and a historian. 
